\title{
Autonomy and accountability in the regulation of the teaching profession: a South African case study
}

\author{
Jonathan D. Jansen* \\ University of Pretoria, Pretoria, South Africa
}

This article examines the struggles of the South African government to establish school-wide evaluation policies within post-apartheid institutions. It is demonstrated that even when such evaluation policies promise teacher development and whole-school improvement, there is significant resistance to government intervention in the school environment. It is also shown that even when individual schools express a willingness to participate in such evaluation actions, they remain deeply suspicious of, and even subvert, the original goals of these policies. The explanation for such behaviour is lodged within the troubled history of the apartheid inspection system, on the one hand, and on the underestimation in policy design of the deep-rooted suspicions of state surveillance systems even under the terms of a new democracy. In conclusion, the article shows how this fierce - though understandable-contestation of school-level autonomy actually works against the long-term developmental interests of both teachers and learners in South Africa's 29,000 schools.

\section{Introducing the argument}

Why would the education officials of South Africa's democratic government, bearing promises of teacher promotion and 'whole school development,' be driven away from the gates of post-apartheid institutions? Why would the nation's largest and progressive teachers organization, the South African Democratic Teachers Union, insist on 'a moratorium' on the entire process of whole school evaluation-despite policy claims to improve the performance of teachers and the development of schools? And why would this most progressive of school development policies, fulfilling many of the demands of the education struggle against apartheid, effectively be stalled almost ten years after the relatively peaceful transition to a democratic state? The thesis pursued in this article is that it is impossible to understand the paradox of resistance to teacher and school development outside of the turbulent history of education, the state and teacher regulation in the decades following the official introduction of apartheid education in the early 1950s. The argument made rests on two inter-related observations. First, that deeply entrenched resistance to state surveillance and control of teaching renders any attempt to regulate the profession subject to suspicion if not outright rejection. Second, that the suite of policies intended to change teachers and schools have not incorporated into their formal designs and implementation strategies adequate recognition of the historical socialization of teachers and teacher organizations against forms of intervention that offer to improve the profession and its institutions. In pursuing these twin arguments I will demonstrate the inadequacy of previous research and conjecture, namely, that teacher rejection of evaluation 'has not been against appraisal per se: the 
majority of teachers want appraisal to be an essential part of their developmentnot a mechanism of enforcing state control' (Chetty et al, 1993, p. 1). This analysis will show that even when appraisal involves teachers, and works in their own interests, deeply held convictions and suspicion of outsiders continue to work against teacher regulation and professional development in the form of external appraisals. The autonomy of teachers' classroom space has become the site of the new resistance in many schools.

\section{The historical context}

The regulation of the teaching profession in South Africa has historically been uneven, unequal and, for long periods of time, unmanageable (Mokgalane et al. 1997). The separate racial and ethnic systems of educational administration could broadly be described as one of coordinated control and regulation for white teachers and one of benign neglect and paternalism for black teachers. Since the formal adoption of apartheid policy in 1948, 'the appointment, discipline and dismissal of [black] teachers were legally in the hands of school boards' (Hartshorne, 1992, p.289). By all accounts, these school boards were ineffective and also unrepresentative of the teachers and communities around the school (The World, 1976, p. 4). The school board of each school consisted of members selected and approved by government.

The career prospects for teachers were very limited and it was not until 1981 that the first black circuit inspector was appointed-but only under the supervision and tutelage of a white circuit inspector. It was the responsibility of the inspector to ensure that the teaching and learning confirmed strictly with the content specifications of the apartheid syllabuses; more broadly, though, these inspectors (responsible for a group of schools in a demarcated circuit) had the task of ensuring compliance with apartheid in all aspects of school functioningfrom governance and administration, to curriculum and assessment.

An authoritative account of this period (1955-1979) holds that:

The school board era was an unhappy one for teachers, did little to advance the interests of teachers, and weakened the profession in its organized negotiations with the central department. It was one of the major causes of the progressive deterioration of the morale of teachers between 1955 and 1980. (Hartshorne, 1992, p. 289)

Since the mid-1970s, a system of inspection was expanded throughout the education system with the goals of enforcing compliance in the face of growing resentment against apartheid education policy—which culminated in the Soweto and later national uprising of youth against the state. A combination of panel inspections (school-wide state assessments of an institution) and subject assessments together monitored and enforced state policy with respect to the curriculum and administration of public schools. The core curriculum for all 
schools, white and black, was reinforced through the dual mechanisms of statedriven inspections and the statemoderated examination system. Any deviation from the state curriculum would therefore be exposed in either the inspection process or in performance on statemoderated examinations. This curriculum contained offensive content (e.g., racial stereotypes), celebrated European conquest, distorted African history, and simply 'left out' major events in the lives and struggles of ordinary African people.

Nevertheless, from oral history testimony of educators at the time, it was 'inspectors... [who] played a central role in subduing teachers and holding them to account' (Soudien, 2002, p. 217). This is not meant to suggest that the state inspection and examination systems ${ }^{1}$ were watertight mechanisms of surveillance; in fact, there is much evidence of 'alternative education' being offered within and around the confines of the official curriculum (Weider, 2002). However, public schools had no choice but to follow the official curriculumalone or in addition to alternatives-or risk the life-chances of their students in the only recognized instrument for gaining access to post-school education and work, the matriculation examination.

The Soweto Uprising of $1976^{2}$ led not only to a rejection of Afrikaans being expanded into black schools as a medium of instruction, but also generated an antagonism among black students and teachers against the entire state apparatus responsible for the administration of apartheid schooling. The most immediate manifestation of this state system of surveillance and control was the school inspectorate. Inspectors visiting black township schools would, invariably, be confronted with hostility and, in several cases, driven away or attacked. Eventually, the department of education simply withdrew this system of inspection in black township schools-given the violence that it unleashed against the state and its officials-leaving behind a telling legacy of suspicion and resentment against state involvement in the supervision and monitoring of teachers and teachers' work within the school environment (see Ndlovu, 1998, especially pp. 14-21). This withdrawal of governmental authority from the professional life of schools also left in its wake a dearth of developmental inputs in the work of teachers, and the lack of effective interventional authority in the disciplining of teachers. But this withdrawal of authority from the professional life of the school was replaced with a violent assertion of the same authority in the political life of the school. For example, in the first twelve months of 1986 about 700 people in the field of education were detained and in 1987 the Department of Education and Training ${ }^{3}$ alone terminated the services of 1585 permanent teachers (Hartshorne, 1999, p. 97) in order to contain anti-apartheid actions among teachers.

By the time of the un-banning of the liberation organizations and the release of Nelson Mandela (in 1990) and his fellow activists from almost three decades of imprisonment, education protests continued to target school inspectors and 
subject advisors, as they were later called. In rare and meticulous research on this subject, Linda Chisholm (1999) found that:

Protests in $1990 \ldots$ took the form of stayaways, chalk-downs, marches to regional offices, submissions of lists of grievances, sit-ins and the prevention of departmental officials from visiting schools ... control personnel such as inspectors and subject advisers were barred from school grounds. At the end of 1990, the total number of principals and others in authority being driven from their posts came to 1991. In 1991 and 1992 the union embarked on strike action and continued with the campaign to eject symbols of an illegitimate department from school grounds. (p. 112)

This was the legacy that would come to haunt the post-apartheid government long after the democratic transition of 1994 and the subsequent pronouncement of a new education and training system.

\section{The regulation of the teaching profession after 1994}

During early transition (1994-1999) there was little effort made to regulate the teaching profession ${ }^{4}$. With the appointment of the second post-apartheid Minister of Education in 1999, an activist and interventionist style of leadership resulted in a number of sacred cows in the teaching profession being taken-on in a very public manner. A number of administrative and political activities were launched with the goal of addressing broad public concerns about the status of the teaching profession and the poor image of teaching in South Africa's 29,000 schools.

First, the senior politicians (including the ANC President, the Minister of Education and the General Secretary of the South African Communist Party) led a series of public attacks on teachers and teaching-some of this on the platform ${ }^{5}$ of the South African Democratic Teachers Union (SADTU), an ally of the ruling party (the African National Congress) within government. These attacks did two things; first, it highlighted an arena of government concern that had not been addressed as directly since national elections of 1994 . Second, it strained relations between SADTU and the government's Ministry of Education which would lead to considerable fallout on a number of other policy platforms, as will be discussed later. In short, to the extent that regulation is an intimately political act, the stage was set by politicians for making teachers accountable as professional actors within public schools that in large measure still bore the unmistakable marks of instability from the 1970s onward.

Second, the government introduced a series of teacher development initiatives intended to strengthen the quality of the largely black teaching force. The teacher development initiatives, on a scale unprecedented in the history of South Africa, were introduced in different forms. One, it was introduced as part of the curriculum reforms in the form of what was called a cascade model of teacher 
training to assist teachers in the implementation of Curriculum 2005-the main ideological venture of the new government for changing the content of apartheid education; this outcomes-based and learner-centred curriculum was to displace the content-driven and teacher-centred curriculum of apartheid (Jansen \& Christie, 1999). Two, it was introduced in the form of a state-funded National Professional Diploma in Education (NPDE) with the explicit goal of upgrading the qualifications of the more than $25 \%$ of under-qualified teachers in the nine provinces of South Africa. Three, the provinces embarked on their own generation of large volumes of donor funding with the specific goal of building teacher capacity especially in subjects like mathematics and science ${ }^{6}$. This large and un-quantified volume of donor funding in many cases presented the main source of teacher development finance in provinces where the high levels of personnel expenditure and the required capital expenditure left very little in the normal provincial budget for teacher development.

Third, government initiated the development of a new teacher education policy, which, after long delays, seeks to provide a comprehensive statement on the growth and development of teachers and the regulation and administration of the teaching profession. This policy, in development at the time of writing, is expected to lead to the first-ever White Paper on Teacher Education.

Fourth, and perhaps most importantly, government supported the launch of the South African Council on Education-a statutory body specifically charged with regulating the teaching profession. The main objectives of SACE are to enhance and improve the quality and standards of the teaching profession through three broad actions:

- The promotion and development of the teaching profession (a development function).

- The registration of educators as one way of maintaining standards of practice (a registration function).

- The establishment and maintenance of a code of professional ethics for educators that will govern the behaviour of every teacher (a regulation function).

The Council has legislative powers to determine criteria for entry into the profession through the process of registration of educators. The definition of 'educator' is broad and inclusive:

Any person who teaches, educates or trains other persons or provides professional therapy at any school, technical college or college of education or assists in rendering professional services or educational auxiliary services provided by or in a department of education... and any other person registered with the council (www.sace.org.za). 
The courageous component of the SACE mandate is the Code of Conduct which carries with it disciplinary measures to be taken against educators registered under the Council, and who act inappropriately within the profession. This would be the first time, since the hated inspection system, that direct intervention to regulate teachers' behaviour would be embarked on. Yet the overall thrust of the SACE policy is positive, as one set of reviewers noted:

The locus of its strength lies in the drive for professionalism among educators, the sensitivity to the unequal power relations that exist between educators and learners (and among educators themselves), and the commitment to ideals of democracy and human rights. (Barasa \& Mattson 1998, p. 54)

Fifth, government raised to symbolic and material visibility, on a scale never seen before, the Grade 12 matriculation examination-the end-of-school examination that continues to be the main determinant of life chances for high school graduates. This remains the most public and contested instrument for holding schools and teachers accountable for the performance of their learners. For the first time in history, individual schools were held accountable for their results by the most senior politician concerned with education-the Minister. Individual school results appeared in the newspapers and schools with very low percentage passes in the matriculation examination were the subject of 'blaming and shaming' on the part of the Minister of Education. The blacklisted schools had their results published prominently and were placed on notice that they were under official surveillance. For the first time, Best Teacher Awards were distributed in the nine provinces and at a national gala evening-with schools making the most progress also receiving public attention at this ministerial function. Poorly performing schools received visits from politicians and bureaucrats alike, and intense pressure brought to bear on these institutions. Within a short period of time, results improved dramatically at both the individual school level and also at provincial levels ${ }^{7}$.

Sixth, government introduced a network of regulatory policies all intended-at least rhetorically - to measure and support improvements in both teacher performance and school development. A comparative analysis of four such documents was recently undertaken by Barasa and Mattson (1998): the Norms and Standards for Educators; the Code of Conduct (mentioned earlier); the Manual for Developmental Appraisal; and Duties and Responsibilities of Educators. This study saw connections among these policies and claimed that:

Together, these documents define employer requirements, provide frameworks for professional development and appraisal, define professional conduct, and specify the duties and responsibilities of educators. (Barasa \& Mattson, 1998, p. 47) 
Table 1. Changes in matriculation pass rates, $1999-2002^{8}$

\begin{tabular}{l|cccc}
\hline & $\mathbf{1 9 9 9}$ & $\mathbf{2 0 0 0}$ & $\mathbf{2 0 0 1}$ & $\mathbf{2 0 0 2}$ \\
\hline No of students & 511,874 & 489,941 & 449,371 & 443,821 \\
No of passes & 249,831 & 283,294 & 277,206 & 305,774 \\
\hline $\begin{array}{l}\text { Percentage pass } \\
\text { rate }\end{array}$ & $48,9 \%$ & $57,9 \%$ & $61,7 \%$ & $68,9 \%$ \\
\hline
\end{tabular}

Source: Department of Education, South Africa, 27 December 2002

Table 2. Summary of the symbolic, regulative and procedural functions of each policy document

\begin{tabular}{|c|c|c|c|}
\hline Policy document & Symbolic function & $\begin{array}{l}\text { Regulative } \\
\text { function }\end{array}$ & $\begin{array}{l}\text { Procedural } \\
\text { function }\end{array}$ \\
\hline $\begin{array}{l}\text { COTEP } \\
\text { (Committee on } \\
\text { Teacher Education } \\
\text { Policy) Norms and } \\
\text { Standards for } \\
\text { Teacher Education }\end{array}$ & $\begin{array}{l}\text { Defines roles and } \\
\text { competences of } \\
\text { an } \\
\text { effective educator } \\
\text { as a } \\
\text { self-directed } \\
\text { professional with } \\
\text { practical, } \\
\text { foundational } \\
\text { and reflexive } \\
\text { competences }\end{array}$ & $\begin{array}{l}\text { Defines employer } \\
\text { requirements and } \\
\text { norms and } \\
\text { standards } \\
\text { for evaluation of } \\
\text { qualifications for } \\
\text { the } \\
\text { National } \\
\text { Department } \\
\text { of Education }\end{array}$ & $\begin{array}{l}\text { Outlines } \\
\text { processes } \\
\text { of quality } \\
\text { assurance } \\
\text { of providers and } \\
\text { programmes for } \\
\text { teacher education }\end{array}$ \\
\hline $\begin{array}{l}\text { SACE Code of } \\
\text { Conduct }\end{array}$ & $\begin{array}{l}\text { Defines and } \\
\text { promotes } \\
\text { the ethical conduct } \\
\text { of } \\
\text { an educator as } \\
\text { one who } \\
\text { upholds the view } \\
\text { of } \\
\text { human rights } \\
\text { embodied in the } \\
\text { Constitution }\end{array}$ & $\begin{array}{l}\text { Determines } \\
\text { criteria for } \\
\text { entry into the } \\
\text { education } \\
\text { profession; } \\
\text { regulates the } \\
\text { ethical } \\
\text { conduct of } \\
\text { professionals }\end{array}$ & $\begin{array}{l}\text { Outlines the } \\
\text { registration } \\
\text { procedures and } \\
\text { disciplinary } \\
\text { mechanisms of } \\
\text { SACE }\end{array}$ \\
\hline $\begin{array}{l}\text { ELRC (Education } \\
\text { Labour Relations } \\
\text { Council) Manual } \\
\text { for Developmental } \\
\text { Appraisal }\end{array}$ & $\begin{array}{l}\text { Defines roles and } \\
\text { competences } \\
\text { (core } \\
\text { criteria) of } \\
\text { effective } \\
\text { educators; }\end{array}$ & $\begin{array}{l}\text { Sets in place a } \\
\text { nationally unified } \\
\text { system of } \\
\text { appraisal to } \\
\text { be followed in all } \\
\text { schools }\end{array}$ & $\begin{array}{l}\text { Outlines structures } \\
\text { and procedures of } \\
\text { appraisal systems } \\
\text { within schools }\end{array}$ \\
\hline
\end{tabular}


encourages

reflective practice,

professional

development and

accountability

\begin{tabular}{|c|c|c|c|}
\hline $\begin{array}{l}\text { National } \\
\text { Department of } \\
\text { Education Duties } \\
\text { and } \\
\text { Responsibilities } \\
\text { of Educators }\end{array}$ & $\begin{array}{l}\text { Defines day-to- } \\
\text { day } \\
\text { duties and } \\
\text { responsibilities of } \\
\text { educators, } \\
\text { assuming } \\
\text { the roles and } \\
\text { competences } \\
\text { outlined } \\
\text { in the above } \\
\text { documents }\end{array}$ & $\begin{array}{l}\text { Provides job } \\
\text { descriptions } \\
\text { against } \\
\text { which educators } \\
\text { can be } \\
\text { legally appointed, } \\
\text { promoted and } \\
\text { appraised }\end{array}$ & $\begin{array}{l}\text { Outlines duties } \\
\text { and } \\
\text { responsibilities of } \\
\text { different post } \\
\text { levels, } \\
\text { thereby clarifying } \\
\text { who should be } \\
\text { doing what within } \\
\text { a } \\
\text { school }\end{array}$ \\
\hline
\end{tabular}

Source: Barasa and Mattson, 1998, p. 47

However, none of these policies generated more public debate and contestations with teachers and teacher organizations than a policy called Whole School Evaluation. In the eyes of the largest teacher union, these evaluation-focused policies were nothing more than the Trojan horse of accountability infringing on and eroding the autonomy of the teaching profession. Or to put it bluntly, this was nothing more than the inspection system in another guise. Given the currency of Whole School Evaluation, its reception in the schools, and its wide-scale implementation problems, this specific form of regulation will require more intensive discussion.

\section{Whole school evaluation as a case in point}

In June 2000, the new Minister of Education (Professor Kader Asmal) introduced the National Policy on Whole School Evaluation (NPWSE) ${ }^{9}$ as follows:

This national policy on whole-school evaluation introduces an effective monitoring and evaluation process that is vital to the improvement of quality and standards of performance in schools ... The findings must be used to re-orientate efforts towards improving the quality and standards of individual and collective performance. (Department of Education, 2000, p. 7)

It was immediately clear from this policy that institutional (the school) and professional (the teacher) performance would, for the first time, be brought into sharp and systematic focus under the new South African Government. 
The key proposals in the policy are the following:

- that schools will initiate a process of self-evaluation during which each school 'provide[s] an account of their current performance' (Department of Education, 2000, p. 11); in this process

- that 'all members of a school should take responsibility for the quality of their own performance. Whole-school evaluation seeks to measure the contribution of both staff and pupils to the school's and their own performance' (p. 12);

- that schools are then subject to a pre-evaluation survey by an accredited supervisor 'to build a brief profile about the general level of functionality of the school' (p. 15). During this visit the self-evaluation reports, along with other school records, are used to generate the school profile;

- that schools are then reviewed and assessed through an external evaluation process by four to six accredited supervisors over a period of three to four weekdays targeting nine focus areas (such as learner achievement) with follow-up surveys (if necessary) every six to nine months in the context of three-year evaluation cycles; and

- that schools would be supported through a post-evaluation process by district support teams 'to implement the recommendations of the evaluation report through school improvement planning that sets clear targets, priorities, time frames and resource allocation' (p. 16).

The key areas for evaluation are the following:

- Basic functionality of the school.

- Leadership, management and communication.

- Governance and relationships.

- Quality of teaching and educator development.

- Curriculum provision and resources.

- Learner achievement.

- School safety, security and discipline.

- School infrastructure.

- Parents and community.

The evaluation will be based on three types of indicators, namely, input indicators (such as learner characteristics, funding levels and number of staff), process indicators (such as quality of teaching) and output indicators (such as standards of achievement and attendance rates). There are discrete 'performance ratings' that will be used on a scale of 1-5 with ' 1 ' signifying an 'unacceptable' rating and ' 5 ' an 'outstanding' score.

The policy on whole-school evaluation, as described above, is important because of the ways in which its frames the discourse of performance in South African 
schools. In this regard, there are several tensions that are generated in the policy proposals.

First, there is tension between school autonomy and state control. At a first glance, it appears that schools are being granted greater autonomy to decide on their own progress, plans and priorities for school improvement. After all, it is the school that measures itself through the self-evaluation process, and these internal documents form the basis for subsequent external evaluations by departmental supervisors. Indeed, 'the authority for the professional management issues of the schools will be vested with the principal of the school, supported by the professional staff' (Department of Education, 2000, p. 20). This means that the principal and staff play a key role in the evaluation processes and in the production of a school improvement plan. Moreover, 'all evaluation activities must be characterised by openness and collaboration. The criteria to be used in evaluating schools, therefore, must be made public' (Department of Education, 2000, p. 12).

However, on closer observation, there are critical areas in which the school principal and staff are excluded from the evaluation process. Consider the following exemption regarding principals:

S/he will participate in the evaluation process by attending meetings, interpreting evidence and clarifying uncertainties but will not be part of decision-making when judgments about the school's performance are made (Department of Education, 2000, p. 21).

In addition, while the co-operative aspects of the evaluation are listed throughout the key policy document, the external evaluators have legal authority to enter and act on a school. Accordingly, 'through the legal responsibilities bestowed on the minister of education, accredited supervisors have the right to enter any school and carry out an evaluation' (Department of Education, 2000, p. 13).

Furthermore, while schools may lay a complaint about 'unfair treatment or unjustified action', the Minister of Education remains 'the final arbiter in any complaint's procedure' (Department of Education, 2000, p. 14).

There is a second tension in the whole-school evaluation between development and accountability. On the one hand, the policy emphasizes the positive benefits for school improvement that comes through internal and external evaluation. Schools will receive district support and development assistance to implement their improvement plans. Schools with benefit from a budget provided to the district to assist implementation. Schools will be exposed to well-trained district officials who will monitor and evaluate the performance of each school. In the words of the Minister: 
Whole-school evaluation is meant to be supportive and developmental rather than punitive and judgmental. It will not be used as a coercive measure, but will ensure that policies are complied with. It will also facilitate support and improvement of school performance using approaches of partnerships, collaboration, mentoring and guidance. (Department of Education, 2000, p. 8)

But what happens if a school does not attain the levels of performance articulated in school improvement plans? Here the policy faces a credibility crisis among practitioners. The largest teacher's union in the country, the South African Democratic Teachers Union (SADTU), has dismissed the policy as nothing more than the old 'inspection system' used under apartheid to force schools into compliance with the State's philosophy and curriculum. The 'inspection system' remains a powerful lens through which the unions interpret this new policy, even though the Minister promises that it is 'less punitive' (Department of Education, 2000, p. 7).

Since new policies are interpreted in relation to other existing policies, there is the added problem that the matriculation examination results are in fact used to blacklist under-performing schools in the system-such schools being listed by name and with all their results in the national newspapers. It is difficult, therefore, to convince practitioners that the policy on whole-school evaluation will not result in some form of reprimand or exposure given how other policies are being implemented in South Africa. The exclusion of school staff from final judgments on their performance does not help to build a developmental understanding of the new policy.

At the end of the day, this new policy, in its own words, is about using performance as a measure of compliance and accountability of the school system to national policy. The policy aims:

- to increase the level of accountability within the system (Department of Education, 2000, p. 11);

- to show to what extent [schools] satisfy the expectations of government and the public and how well they are responding to their accountability for the outcomes of schooling (p. 11); and

- to ensure that policies are complied with (pp. 8-9).

There are political consequences if a lack of compliance with national policy and the constitution are observed; thus, 'should the evaluation reveal problems in complying with the provisions of the constitution, the political head of education in the affected province would have to account to the Minister in writing within ninety days' (Department of Education, 2000, p. 9).

How well did this policy seeking, among other things, regulation and accountability in the teaching profession, fare in practice? 


\section{Emerging evidence of whole school evaluation in practice}

In most of South Africa's nine provinces, the WSE policy has not as yet taken off because of ongoing contestations between the teacher unions and government as driver of this policy. As late as May 2002, the National Executive Committee of the South African Democratic Teachers Union issued a news statement in which they 'resolved to oppose the implementation of the Whole School Evaluation Programme as imposed by the education department' (SADTU, 2002, p. 1) —on grounds that the policy was imposed, and that it was punitive and not developmental.

There was one province in which WSE was not strongly contested and in which implementation proceeded during $2002^{10}$. It was in this context that the first indepth study of the reception and implementation of WSE was recently researched by Anusha Lucen (2003) in her Tracing the implementation trajectory of an education policy: the case of whole school evaluation. Lucen (2003) chose a school that was eager and willing to implement the new policy, and with substantial resources (a former white, privileged institution) to cancel out explanations that might reside in 'the lack of' a material base for education reform. This study found the following:

- That the school responded to the new policy on the basis of its practicality within the immediate school environment. Important parts of the policy were simply ignored given the contingent nature of other policies already operating in the environment.

- That the school responded to the new policy on the basis of knowledge available to them about its design and intent. Again, whole sections of the policy implementation were left out simply because the school was not fully informed of requirements for implementation-such as the need to elect a local coordinator.

- That the school responded to the new policy with considerable confusion, given that three different evaluation policies were operating in the school environment at the same time.

These three findings are not completely unexpected in the broader literature on education change. But what was striking in this case-a school with considerable enthusiasm for the new policy-was the built-in, institutional memory of apartheid inspections and how this mediated the responses of the school to Whole School Evaluation. In the words of the researcher:

... the majority of teachers at Wagpos (the school) are experienced teachers (over ten years of teaching experience) who have been through several inspections in the past. Many recounted vividly the negative experiences of inspections and the profound influence this had on their understanding of the new WSE policy. (Lucen, 2002, p. 252). 
As a consequence, the responses of teachers was one of fear, suspicion and unease towards the visiting evaluators; there was the tendency to resort to 'window dressing' to impress the government officials; and there remained the expectation of some form of reprisal once the evaluators left. Strikingly, once the evaluators left, 'teacher appraisal and development ceased altogether in the school environment' (Lucen, 2003, p. 261).

This is a single study of one case and clearly there will be more evaluative studies on the implementation of whole school evaluation in the future. But for now the evidence on the effects of policy seeking greater accountability point in one direction: the legacy of inspections continue to influence and shape the responses, attitudes and outcomes of policy at the level of schools and classrooms.

\section{Towards a conclusion}

In the range of instruments available to the state for regulating teachers, the most effective is the direct pressure via matriculation results. What accounts for the relative success of matriculation pressures over external evaluations (such as WSE) or statutory councils (such as SACE and its Code of Conduct) or official reprimand (such as union or political platform speeches) or employment specifications (such as the Norms and Standards for Educators)?

First, the matriculation examination concerns learners, and teacher performance is directly related to learner performance as measured in matriculation scores. Second, the matriculation examination is a public record of performance, and this is a reflection not only on teachers but also on schools. Third, the matriculation examination determines the fate of learners more than any other examination in 12 years of schooling; it determines who goes to university, who has to repeat schooling in some form, who gets shunted into perceived lower forms of technical education, and who remains unemployed. Fourth, these public examination results determine for many schools their future enrolments and, therefore, the amount of funding the school qualifies for, the number of teachers that can be employed, and the number of senior positions that can be aspired to. Schools with persistently poor results will attract fewer learners and, when they do, will attract weaker learners - thereby sustaining the vicious cycle of substandard results. It is small wonder that many schools now advertise their matriculation passes in newspapers, on school notice boards facing the roads, and in official brochures of the institution. Parents have a direct interest in learner performance at the matriculation levels; and they vote with their feet depending on those results. This is one of the reasons why black township schools are being depleted of learners as parents—at some costs—move their children great distances to the deracialised white schools perceived as offering better results (Nzimande, 2003). 
In sum, official pressure on matriculation performance matters because parents make decisions based on learner achievement in Grade 12. Parental decisions are not directly based on teacher achievement but on the overall contribution of the school to learner achievement. Moreover, such decisions are not based on performance in Grades 1 through 11, but on the final school examination in Grade 12; not on the processes of schooling, as such, but on the quality of the final product at the end of schooling. And those decisions have consequences for the long-term viability and character of the school. It is for this reason that the Minister's decision to 'blame and shame' under-performing schools, in terms of their matriculation results, has provoked such sharp increases in matriculation scores across South Africa ${ }^{11}$.

But there is also downside to the dominant ways in which schools respond to accountability pressures - that is, by optimising matriculation results on the one hand, and, on the other hand, by resisting state intervention through schoolfocused evaluation.

First, what is the downside to maximizing results? When targets become a national or international preoccupation, there is the real danger-and emerging evidence this effect-that the drive to attain such targets at worst, does serious damage to the educational process, and at best, privilege the measurable (see Gorard et al. 2002). As already mentioned, South Africa has witnessed a strong governmental drive to enhance the end of school examination results in the nine provinces - this is commonly referred to as 'matric' or the matriculation examination (Jansen, 2001). Schools that under-perform are listed through publication of their results in national newspapers. Provinces (responsible for schools) in turn face enormous pressure from below (parent communities) and from above (the national government) to improve the performance of the schools under their jurisdiction. Ultimately, individual learners find themselves under enormous pressure from school principals and teachers to perform adequately, leading to all kinds of dubious practices in the schools. Schools register students on lower grades within the standard to enhance average performance; schools hold back students in earlier grades to ensure that Grade 12 results are enhanced; schools divert students into subject streams that are perceived to be academically less challenging, and therefore likely to deliver better results; and schools refuse re-entry to repeaters rather than risk such students bringing down the school average. In the process, two things happen. First, the educational responsibility to deepen and extend learning opportunities is lost in a mad scramble to 'push-up' results that relieve schools, provincial bureaucracies and politicians from pressures for what is called accountability. Second, the educational responsibility to provide adequate resources through well-trained teachers and productive learning environments gives way to the preoccupation with outcomes or end-results-achieved at any cost.

In the USA and English contexts, studies point to 'the distorting effects of high stakes target setting' (Goldstein, 2002, p. 2) when external pressures force 
individuals to change their behaviour in the direction of the reward system. To be sure, under such target-driven pressures, test scores might increase in the short term-but at a cost with respect to learner motivation, test anxiety, the narrowing of the curriculum (teaching to the test) and long term or sustained achievement gains. Reviewing this evidence, Harvey Goldstein (2002) concludes that:

In both England and Texas we see evidence that when learning outcomes are made the focus of targets, those who are affected will change their behaviour so as to maximize their 'results', even where this is dysfunctional in educational terms. (p. 4)

It is this process of succumbing to external pressures in the name of accountability that I have called 'the politics of performance' (Jansen, 2001, p. 625; see also Jansen, 2003) in developing states. It is a response that is particularly devastating to under-resourced schools and poor learners, for the elevation in test scores distracts from the reality that such learners remain underprepared in terms of their broader academic preparation for further study or in their skills preparation for the world of work. It leaves such learners without the competence and confidence to successfully engage the workplace or higher education-notwithstanding that fact that the political goals of those who exert such pressure on schools appear to be served.

Second, what is the downside to resisting state intervention? Such resistance means that teachers, teaching and the overall professional behaviour of educators remained relatively immune from public or governmental scrutiny. Teachers have successfully, in this context, been able to secure their classrooms as autonomous spaces free from outside interference-even if it comes packaged in the name of teacher development. These autonomous spaces are defended on the basis of a powerful institutional and political memory from the past-the devastating practice of 'inspections' from the apartheid era. The largest teacher union has sensed the power of this memory in being able to mobilise against state intrusion whether in the name of accountability or development. Our interviews with teachers suggest that these autonomous spaces within schools will constitute a major battleground for future state accountability and development policies, unless such measures are enforced at a safe distance from the day-to-day practice of teachers-as in the matriculation examinations.

These autonomous spaces should not, however, be romanticised. It is particularly dangerous given the fact that at least $25 \%$ of South African teachers are under-qualified and a majority under-prepared to deal with the demands of curriculum innovation, new assessment technologies and -at a very basic levelaccurate teaching of the subject matter. Time after time, anecdote and research in South Africa have demonstrated that factual errors in subject teaching are commonplace, and that 'difficult' content is simply avoided by teachers who lack the confidence and competence to teach, especially in high schools. In such contexts, classroom observations by peers within the school and/or by evaluators 
from outside the school can play a significant role in building the subject matter competence and professional confidence of teachers in this developing country context. The rigid defense of autonomy means that another generation of learners would be underserved by poor teaching, that misconceptions in subjects like mathematics and science would be sustained, and that teachers would simply stagnate in terms of their professional development. Argued from another angle, substantive accountability (the vital but broader intellectual engagement of teachers and learners in the classroom) suffers under these conditions even as coercive accountability continues to exact its toll in terms of matriculation outcomes. Frederick Hess (2002) makes this point eloquently, in another context:

High stakes accountability may marginalize many of the other roles that schools play, reallocate educator energy and resources, and narrow the scope of instruction. (p. 73)

The only way in which to reverse this institutional attitude towards external evaluation and support in South Africa is to demonstrate slowly and systematically that such interventions indeed function in the interests of teachers. And this may mean suspending in the short-term any aspirations for external, evaluation-driven accountability in favour of internal, peer-driven teacher development and, as a consequence, South African schools might possibly secure a much more vibrant and defensible notion of teacher autonomy.

\section{Notes}

1. The examination system functioned in ways that reinforced the content of the state curriculum (or syllabuses as they were called). In other words, the examination system, based largely at the time on rote reinforcement of content knowledge, ensured compliance with official knowledge.

2. The immediate causes of the Soweto Uprising was the enforcement of the Afrikaans language (the dominant language of the state) but the deeper causes lay in the rejection of the education system as a mechanism to enforce subservience of black people-and, ultimately, a rejection of the entire apartheid system.

3. This was the department with administrative control over the education of 'urban Africans' as distinct from those black persons restricted to the ethnic and rural 'homelands' of apartheid.

4. The apartheid administration structures were slowly dismantled in early transition, with old style officials remaining in many senior positions during the first 2-3 years. This gradual transformation was in part a response to the political environment that required reconciliation and gradualism given the negotiated terms of the settlement between (in the main) African and Afrikaner nationalists. By 1999, the distribution of personnel had changed dramatically even though the administrative culture of the previous system still extended into many parts of the new government bureaucracy. 
5. One such attack was made by ANC President Mbeki on the occasion of the Fourth National Congress of the South African Democratic Teachers Union in September 1998, where he urged SADTU to 'purge itself of its image as a toyitoying teachers union that cared only about salaries.' (Mbeki, 1998, p. 1) Toyitoying is a political dance, often accompanying protest marches, and associated with the liberation movement from its days in exile.

6. In post-apartheid South Africa, the provinces were at liberty to approach and receive funding from foreign governments for provincial functions like teacher development and curriculum reform.

7. The dramatic improvement in results, as shown later in this paper, was artificial and therefore not sustainable. It certainly was not the result of alterations in the substance of teaching or the meaningfulness of learning that characterize 'deep change.'

8. Whole School Evaluation, like so many other evaluation policies of the new government, did not flow logically from either changes in school examination performance or emerge in articulation with existing policies. It had its own life cycle, and this remains at the route of much confusion among schools.

9. The data represented in Table 1 shows an incline in matriculation passes and a corresponding decline in the number of candidates showing up to write the Grade 12 examinations over the five-year period. There is as much speculation about the reasons for the drop in candidacy (such as the impact of HIV/AIDS, the dropping out of boys into gang cultures etc) as there is for the rise in passes (such as the ejection of 'repeaters' from schools and the enrolment of learners on lower subject grades-making passes easier). There is, however, little research to make definitive statements about the actual factors at play-though commonsense suggests they all play some role in this regard.

10. It is not immediately clear why this province did not resist WSE but possible reasons include the rural character of the province and the relative lack of strong union influence in this particular setting - compared to the volatile urban settings like Gauteng province.

11. It is a sad commentary on the quality of the examination itself that such dramatic improvements in Grade 12 results can be stimulated by superficial changes in educator and institutional behaviour. In other words, examinations continue to privilege content and rote learning - which makes such results possible.

\section{References}

Barasa, F. S. \& Mattson, E. (1998) The roles, regulation and professional development of educators in South Africa: a critical analysis of four policy documents, Journal of Education, 23, 41-72.

Chetty, D., Chisholm, L., Gardiner, M., Magau, N. \& Vinejold, P. (1993)

Rethinking teacher appraisal in South Africa: policy options and strategies. Paper presented at the Center for Education Policy Development Conference on

Teacher Policy, Broederstroom.

Chisholm, L. (1999) The democratization of schools and the politics of teachers' work in South Africa, Compare, 292, 111-126. 
Department of Education (2000) The national policy on whole school evaluation, Government Gazette, Vol. 433, No. 22512, Pretoria, South Africa.

Goldstein, H. (2002) Education for all: the globalisation of learning targets. Paper presented at the Education for All Conference, Institute of Education, November 22 (to be published in Research Intelligence, 2003).

Gorard, S., Rees, G. \& Selwyn, N. (2002) The 'conveyor belt effect': a reassessment of the impact of national targets for lifelong learning, Oxford Review of Education,281, 75-89.

Hartshorne, K. (1999) The making of education policy in South Africa (Cape Town, Oxford University Press).

Hartshorne, K. (1992) Crisis and challenge: black education 1910-1990 (Cape Town, Oxford University Press).

Hess, F. (2002) Reform, resistance ... retreat? The predictable politics of accountability in Virginia, in: D. Ravitch (Ed.) Brookings papers on education policy (Washington, DC, Brookings Institution Press), 69-122.

Jansen, J. D. (2003) Targeting education: the politics of performance and the prospects of education for all. Plenary address, 7th Biennial Oxford Conference on Education, University of Oxford, 7-9 September.

Jansen, J. D. (2001) On the politics of performance: autonomy, accountability and assessment, Prospects: A Quarterly Journal of Comparative Education, XXXI4, 625-638.

Jansen, J. D. \& Christie, P. (1999) Changing curriculum: studies in outcomes based education in South Africa (Cape Town, JUTA Academic Press).

Lucen, A. (2003) Tracing the implementation trajectory of an education policy: the case of whole school evaluation. Unpublished PhD dissertation, University of Pretoria, South Africa.

Mbeki, T. (1998) Teachers who live by the rules of criminals, Sunday Times, 13

September, p. 1.

Mokgalane, E., Carrim, N., Gardiner, M. \& Chisholm, L. (1997) The National

Teacher Appraisal Pilot Project Report

(Education Policy Unit, University of the Witwatersrand, Johannesburg).

Ndlovu, S. M. (1998) The Soweto uprisings: counter-memories of June 1976 (Johannesburg, Ravan Press).

Nzimande, B. (2003) Notes from fieldwork on 'the commonsense decisions of black South African parents who send their children to former white schools' (School of Education, University of Wisconsin).

SADTU (2002) SADTU Calls for urgent moratorium on whole school evaluation. South African Democratic Teachers Union Media Release, 17 May. Available online: www.sadtu.org.za/press/2001/17-5-2002.0.htm.

Soudien, C. (2002) Teachers' responses to the introduction of apartheid education, in: P. Kallaway (Ed.) The history of education under apartheid 19481994: the doors of learning and culture shall be opened (New York, Peter Lang), 211-223.

The World (1976) The school boards are toothless, Friday, May 21, p. 4. Weider, A. (2002) Informed by apartheid: mini-oral histories of two Cape Town teachers, in: P.Kallaway (Ed.) The history of education under apartheid 1948- 
1994: the doors of learning and culture shall be opened (New York, Peter Lang), 197-210.

*Dean's Office, Faculty of Education, Groenkloof Campus, University of Pretoria, Pretoria, 0001 South Africa. Email: djansen@postino.up.ac.za 